\title{
Enhanced Coagulation: Promising Findings and Challenges
}

\author{
Djamel Ghernaout ${ }^{1,2 *}$ \\ ${ }^{1}$ Chemical Engineering Department, College of Engineering, University of Ha'il, Ha'il, KSA \\ ${ }^{2}$ Chemical Engineering Department, Faculty of Engineering, University of Blida, Blida, Algeria \\ Email: *djamel_andalus@hotmail.com
}

How to cite this paper: Ghernaout, D. (2020) Enhanced Coagulation: Promising Findings and Challenges. Open Access Library Journal, 7: e6569.

https://doi.org/10.4236/oalib.1106569

Received: July 1, 2020

Accepted: July 14, 2020

Published: July 17, 2020

Copyright (C) 2020 by author(s) and Open Access Library Inc.

This work is licensed under the Creative Commons Attribution International License (CC BY 4.0).

http://creativecommons.org/licenses/by/4.0/ (c) (i) Open Access

\begin{abstract}
The coagulation process remains one of the fundamental treatment techniques for treating water and wastewater. Enhancing the coagulation process is more and more a popular research topic. This work focuses on the implementation of chemical oxidation-enhanced coagulation (EC). It also discusses distinguished findings and innovations of EC and its main dares and trends. Pre-oxidation remains widely employed in dealing with water carrying algae and ameliorates coagulation by breaking the organic coating and modifying the surface potential of particles, even if precautions should be adopted to avoid algal organic matter release. EC remains importantly influenced by practical variables such as mixing conditions and coagulation process control. As a perspective, modeling mathematically EC is more than requested. Employing ozonation with GAC could also be adopted and estimated in situations where EC is utilized.
\end{abstract}

\section{Subject Areas}

Chemical Engineering \& Technology

\section{Keywords}

Enhanced Coagulation (EC), Dissolved Organic Matter (DOM), Algae, Disinfection By-Products (DBPs), Charge Neutralization

\section{Introduction}

The coagulation process remains one of the most frequent phenomena in nature and industrially applied water treatment techniques [1]. During coagulation, colloids are merged into bigger flocs [2]. On such aggregates, dissolved organic matter (DOM) is adsorbed [3] [4]. Therefore, such pollutants could be elimi- 
nated during the next solid/liquid separation techniques (especially, decantation and sand filtration) [5]. The pathway for eliminating organic matter (OM) by coagulation possesses three major manifestations [6]. During the first one, positively charged metal ions $\left(\mathrm{Fe}^{3+}, \mathrm{Al}^{3+}\right)$ and negatively charged particulate organic matter (POM) are electrically neutralized and aggregated [7]. During the second one, metal ions and DOM molecules constitute insoluble complexes and precipitates and finally, throughout the last one, physicochemical adsorption of DOM takes place on the surface of metallic hydroxide (i.e., $\mathrm{Fe}(\mathrm{OH})_{3(\mathrm{~s})}$ or $\left.\mathrm{Al}(\mathrm{OH})_{3(\mathrm{~s})}\right)$ [3] [8]. Ecological contamination issues are worsening and water quality standards are beginning to be stricter; thus, traditional coagulation technique becomes inapt to remove DOM [9]. Therefore, enhanced coagulation (EC) and optimized coagulation were suggested founded on present water treatment plants and via taking into account the working circumstances of preceding and following stages to attain the target of advanced water treatment [10] [11] [12] [13]. EC adopts maximized total organic carbon (TOC) elimination as its unique aim, which is comparable with optimized coagulation (maximize turbidity, particulate TOC and DBPs precursor reductions, and minimize residual coagulant, sludge production and operating costs) in drinking water treatment practice [14] [15].

In fact, the idea of EC is suggested by the American Hydraulic Association in the 1990s in order to ameliorate the OM reduction via augmenting the injection of coagulant in the traditional coagulation method while assuring the elimination of colloids [16] [17]. Increasing the coagulant dosage is ensured by the coagulation $\mathrm{pH}$ circumstances [18]. Further, optimized coagulation is suggested founded on EC [19] [20] [21].

Lately, there is a growing interest in the study of EC [22] [23] [24]. Special focus was accorded to (1) comprehend the properties of OM in water supplies [25] [26], (2) define OM reduction rules to determine an OM reduction strategy [27] [28] and, (3) define the pathways of EC elimination of OM. Elevating OM removal performance is related not only to the coagulant injection and water $\mathrm{pH}$, but also to the nature and distribution of the $\mathrm{OM}$ and solid matter in the water, implying the temperature, hydraulic condition, and coagulant morphology [29]. Since the idea of contaminants in water supplies is more and more extended and their removal is progressively more and more difficult [30], procedures to support coagulation are becoming more varied [31]. As an illustration, permanganate oxidation-assisted coagulation has been largely adopted to ameliorate turbidity, NOM, and algae removal during the coagulation method [32] [33]. Ballast microsand and magnetic powder could be viewed as fully developed techniques, comprising "Actiflo" technique and "CoMag" technique [13] [34] [35] [36]. Utilizing ballast technology is as well more ameliorated in dealing with wastewater. Researchers investigated the effect of introducing powdered activated carbon (PAC) or organoclay (OC) adsorbent and ferric chloride $\left(\mathrm{FeCl}_{3}\right)$ coagulant jointly on the coagulation efficiency [3] [37] [38]. They found that the turbidity of the clarified water was smaller if OC was injected throughout the 
coagulation stage and PAC reduced more than half or almost all of the dissolved aromatic compounds. Scientists employed synthetic hydroxyapatite in integration with chitosan and illustrated that it could efficiently eliminate $88 \%-95 \%$ of copper and zinc ions. One more common research trend is suggesting and employing novel coagulants, like inorganic polymer flocculants, biopolymer flocculants and natural coagulants [39]. However, several issues appear below implementing EC [17] [40]. As an illustration, pre-oxidation risks to harm the cell membrane, conducting to toxin liberation and augmented taste and odor [41]. Further, introducing microsand will negatively influence the pump maintenance. Consequently, it is indispensable to investigate the running pathway, dares and novel revelation related to boosting the coagulation phenomena to decrease its drawbacks.

This work focuses on the implementation of chemical oxidation-EC. It also discusses distinguished findings and innovations of EC and its main dares and trends.

\section{Chemical Oxidation-Enhanced Coagulation (EC)}

Investigating chemical oxidization-EC remains one of the problem areas in the water treatment study [40] [42]. The major driving forces stay to decrease the poisoning of conventional oxidation and ameliorate the coagulation performance. In numerous water treatment plants, potassium permanganate $\left(\mathrm{KMnO}_{4}\right)$ pre-oxidation as an easy EC technique has been efficiently implemented [43]. Further, several pre-oxidants (like ferrate [44] [45] [46], ozone [47] [48], permanganate complex agents, persulfate, Fenton reagents $\left(\mathrm{Fe}^{2+}+\mathrm{H}_{2} \mathrm{O}_{2}\right)$ [49] [50] [51], and sodium hypochlorite [52] [53] [54]) have been suggested [13] [40].

\subsection{Practical Concepts}

Even if the route of pre-oxidation for ameliorating coagulation efficiency is not identical to other oxidants, the expansion of pre-oxidation is commonly pointed at varying the zeta potential via destroying the organic coating on the surface of the particles [55]. This will leads to formation of aggregates [13] [56].

\subsection{Chlorine $\left(\mathrm{Cl}_{2}\right)$ and Chlorine Dioxide $\left(\mathrm{ClO}_{2}\right)$}

It is well known that chlorine is a disinfectant [57] [58]. Chlorine could be injected as an oxidant of a little polluted water (i.e., surface water) to reduce color and taste. Chlorine has not been largely employed to ameliorate coagulation; however, chlorine as pre-oxidant has the potential to ameliorate coagulation and increase the reduction of algae cells [59] [60] [61]. For treating drinking water, chlorine dioxide is frequently produced from sodium chlorite reacting with $\mathrm{Cl}_{2}$, hypochlorous acid, or hydrochloric acid. Identically to chlorine, $\mathrm{ClO}_{2}$ pretreatment possesses a favorable influence on algae reduction. Scientists [13] proved that $\mathrm{ClO}_{2}$ injection possesses an interesting capacity to decrease algae viability and oxidize ionic and complexed soluble manganese. Researchers [13] estab- 
lished that the optimal injection of $0.5 \mathrm{mg} / \mathrm{L}$ of $\mathrm{Cl}_{2}$ could avoid the eruption of Pseudomonas aeruginosa. Chlorine dioxide pre-oxidizing could demolish the cell walls of algae, conducting to the grave decomposition of membrane glycoproteins or some amino acids. Decreasing cell integrity using $\mathrm{ClO}_{2}$ pre-oxidation considerably ameliorates the reduction of algae via the coagulation precipitation technique. Nevertheless, $\mathrm{ClO}_{2}$ pre-oxidizing only possesses a restricted impact when dealing with surface water that carries little or no algae. Scientists [13] introduced 0.6 and $1.0 \mathrm{mg} / \mathrm{L}$ of $\mathrm{ClO}_{2}$ for pre-oxidizing the potable water and noted no crucial amelioration in potable water quality. Further, $\mathrm{NaOCl}$ has the potential to infiltrate the cell membrane of Microcystis aeruginosa inducing the liberation of intracellular organic matter (IOM) and potassium ions $\left(\mathrm{K}^{+}\right)$from the cells, because of that demolishing cell chemosphere and increasing the reduction of the algae via coagulation.

\section{3. $\mathrm{O}_{3}$}

Ozone is a strong disinfectant and oxidant [47] [48]. Since 1906, it has been utilized in water treatment plants in Europe [13]. Ozone has several applications as it is employed to kill pathogens, decolorize, demobilize algae, and decrease inorganic substances [47]. In the water treatment industry, $\mathrm{O}_{3}$ has numerous merits: (a) it neutralizes chlorine-resistant viruses and spores [27] [28] [30] [62]; (b) it is rarely influenced by sewage $\mathrm{pH}$ and temperature; (c) it eliminates color, odor, and phenols from sewage, augments the dissolved oxygen level, and ameliorates water quality; (d) it could increase the biodegradability of contaminants; and (e) it is hard to decompose and will not form side contamination due to residues. Consequently, it has been largely tested and utilized. Researches established that reasonable injections of $\mathrm{O}_{3}$ ameliorate coagulation yield. Some interpretations have been suggested [13]: (1) $\mathrm{O}_{3}$ oxidation could augment the level of oxygenated functional groups on solid surfaces (like carboxylic acids), conducting to complexation with cations (e.g., $\mathrm{Ca}^{2+}, \mathrm{Mg}^{2+}, \mathrm{Al}^{3+}$, etc.) and generation of metal humic acid complex precipitates [63]; (2) $\mathrm{O}_{3}$ could transform high-molecular-weight compounds into low-molecular-weight compounds, decreasing space and electrostatic repulsion, and ozonation decreases the stabilization of organic chemicals that cover the surface of particles, which leads to their desorption; (3) ozonation polymerizes metastable organic compounds, which leads to particle aggregation via bridging reactions; (4) ozonation modifies the surface chemistry of organic chemicals and augments coagulation via charge neutralization.

As a pre-oxidant, $\mathrm{O}_{3}$ has been largely utilized to ameliorate coagulation. Further, $\mathrm{O}_{3}$ remains frequently employed to remove NOM, algae, heavy metal ions, humus, and dye wastewater. NOM is adsorbed on the colloids and minerals' surface [3]. Researchers [13] established that ozone could cause the aggregation of NOM. Other researchers [13] found that $\mathrm{O}_{3}$ as a pre-oxidant possesses a more considerable influence on coagulating colloids in the water of moderate hardness 
than on coagulating colloids in soft water. Scientists [13] focused on the pathway of $\mathrm{O}_{3}$ reduction of NOM and discovered that $\mathrm{O}_{3}$ could induce colloidal instability only in the occurrence of calcium. They suggested a hypothesis founded on electrostatic complexation/charge neutralization and calcium oxalate precipitation: (i) the components of ozonated NOM could complex with calcium and, (ii) the ozonation of NOM augments the number of coordination sites on the surface and the complexation of NOM with calcium is comparatively easy. Numerous investigations [13] focused on the most important variables that touch the $\mathrm{O}_{3}$ performance in coagulating NOM: the properties of the surface water (hardness, $\mathrm{pH}$, alkalinity, and kind and level of $\mathrm{NOM}), \mathrm{O}_{3}$ injection, and coagulation parameters (i.e., coagulant's injection and kind). As a pre-oxidant, $\mathrm{O}_{3}$ could be employed in integration with additional oxidants (Fenton, permanganate, etc.). Applying $\mathrm{O}_{3}$ as a pre-oxidant stays so promising to improve coagulation yield.

As a rule, only small quantities of $\mathrm{O}_{3}$ could increase the coagulation performance, and, however, elevated injections of $\mathrm{O}_{3}$ can augment the turbidity of the definitive water. The best injection of $\mathrm{O}_{3}$ is at all times intimately linked to the NOM charge density. The higher the charge density of NOM is, the higher the needed injection of $\mathrm{O}_{3}[13]$.

\subsection{Permanganate}

Permanganate illustrates elevated reactivity in oxidizing a large set of organic and inorganic compounds. Permanganate is mostly introduced to deal with odor and taste, reduce iron, manganese, and algae and work as a killing agent. The concept of permanganate pre-oxidation to ameliorate coagulation performance may be explained by the fact that permanganate is oxidized to form manganese dioxide $\left(\mathrm{MnO}_{2}\right)$, which is a powerful adsorbent and could elevate the flocculation dynamics via elevating the particle concentration. As a pre-oxidant, permanganate could efficiently reduce heavy metals and OM [13].

During the last thirty years, permanganate as pre-oxidant for enhancing coagulation efficiency has caught growing interest. In the water treatment plant, cyanobacteria could generate metabolites or toxins that are hard to eliminate via classical water treatment technology [2] [4] [41]. As a result, pre-oxidation techniques are largely employed (e.g., $\mathrm{Cl}_{2}, \mathrm{O}_{3}, \mathrm{ClO}_{2}$, and $\mathrm{KMnO}_{4}$ ). Since $\mathrm{Cl}_{2}$ and $\mathrm{ClO}_{2}$ could generate $\mathrm{DBPs}, \mathrm{KMnO}_{4}$ usage as pre-oxidant becomes largely employed. Indeed, scientists [13] noted that $\mathrm{KMnO}_{4}$ could considerably ameliorate the coagulation of water via the production of the powerful adsorbent $\mathrm{MnO}_{2}$, which adsorbs onto colloids' surfaces. Further, researchers [13] discovered that $\mathrm{MnO}_{2}$ adsorbs humus only when $\mathrm{Ca}^{2+}$ is existing. Scientists [13] found that augmenting $\mathrm{Ca}^{2+}$ level, the settling velocity was importantly augmented and $\mathrm{Ca}^{2+}$ enhanced permanganate contribution via electrically neutralizing surface bridging. In addition to permanganate integration of algae flocs to augment settling velocity, the introduction of $\mathrm{KMnO}_{4}$ could also cause algal cells to liberate OM. Scientists [13] proved that the flocculating performance of roughly destroyed algae is so minimal. Indeed, maters with extremely elevated molecular weight (MW) will 
bond to the coagulant, inducing its failure, which may also decrease the coagulation performance. Further, $\mathrm{KMnO}_{4}$ is utilized at a usual injection $(0-2 \mathrm{mg} / \mathrm{L})$. Therefore, there is a small deterioration of algal cells. Researchers [13] examined the harm of the $\mathrm{KMnO}_{4}$ injection to algae $\left(\mathrm{KMnO}_{4}\right.$ dosages were $1 \mathrm{mg} / \mathrm{L}, 2$ $\mathrm{mg} / \mathrm{L}$, and $6 \mathrm{mg} / \mathrm{L}$ ). A suitable injection of $\mathrm{KMnO}_{4}$ (e.g., $2 \mathrm{mg} / \mathrm{L}$ ) contributed to extracellular organic matter (EOM) secretion via algae. Researchers [13] illustrated that EOM could ameliorate the integration of algae flocs and $\mathrm{MnO}_{2}$ and attain the aim of EC. Further, immoderate manganese $(>2 \mathrm{mg} / \mathrm{L}$ ) will touch the effluent water standard. As a rule, excess $\mathrm{MnO}_{2}$ is reduced via a decantation tank throughout the water treatment, even if it augments the load on the sand filter and reduces the backwash cycle. The properties of the raw water require to be examined to guarantee the total transformation of the peracid salt into $\mathrm{MnO}_{2}$. The drawbacks of $\mathrm{KMnO}_{4}$ pre-oxidation are controlled to enhance coagulation to the highest level.

\subsection{Ferrate}

As an interesting chemical agent, ferrate could be viewed as coagulant and oxidant in dealing with water and wastewater [44] [45] [46]. It possesses a powerful redox potential (from $2.2 \mathrm{~V}$ in acidic $\mathrm{pH}$ to $0.7 \mathrm{~V}$ in alkaline conditions) [46]. Throughout the reduction of ferrate, with the formation of $\mathrm{Fe}(\mathrm{OH})_{3(\mathrm{~s})}$, hydrolyzed substances with an elevated positive charge could be formed [46]. Such hydrolysates will conduct to colloids, push the particles to be electrically neutralized, and adsorb water molecules and fine particles, therefore augmenting the settling velocity of the coagulation [44]. In only $1 \mathrm{~min}$, ferrate could destabilize colloids, whilst iron salts require $30 \mathrm{~min}$ to reach stable findings [13]. Moreover, ferrate may be viewed as an emerging multifunctional oxidant, disinfectant, and coagulant. Ferrate does not form any DBPs in water treatment. It is a green water and wastewater treatment product [44] [45] [46]. It is well accepted that ferrate could efficiently reduce several organic and inorganic contaminants (e.g., nitrogenous organics, drugs, antibiotics, algae, etc.) and different metals (like $\mathrm{Mn}^{2+}, \mathrm{Cu}^{2+}, \mathrm{Pb}^{2+}, \mathrm{Cd}^{2+}, \mathrm{Hg}^{2+}, \mathrm{Fe}^{2+/ 3+}, \mathrm{Cr}^{3+}$, etc.). Ferrate was found better than $\mathrm{Fe}\left(\mathrm{SO}_{4}\right)$ below low-dose circumstances when dealing with colored solution. Ferrate has the potential to efficaciously decrease the $\mathrm{UV}_{254}$ and turbidity of water. As a pre-oxidant, ferrate was successfully employed to ameliorate coagulation and deal with water carrying algae. Using electrochemical technology, scientists [13] fabricated potassium ferrate $\left(\mathrm{K}_{2} \mathrm{FeO}_{4}\right)$ and proved that $1 \mathrm{mg} / \mathrm{L} \mathrm{K}_{2} \mathrm{FeO}_{4}$ and $10 \mathrm{mg} / \mathrm{L}$ iron salt reached an identical treatment impact. The degradation velocity of ferrate is a function of the $\mathrm{pH}$ degree, water temperature, initial $\mathrm{K}_{2} \mathrm{FeO}_{4}$ dosage, and coexisting ions.

\section{Enhanced Coagulation (EC): Distinguished Findings and Innovations}

To satisfy requirements for water quality and algal control, $\mathrm{Hu}$ et al. [64] em- 
ployed micro-ozone, $\mathrm{KMnO}_{4}$, ferrate, and chlorine dioxide as pre-oxidants. Throughout chlorination and chloramination, the generation of usual carbonaceous disinfection by-products (C-DBPs) and emerging nitrogenous disinfection by-products (N-DBPs) was examined integrating numerous techniques: (i) coagulation-sedimentation-filtration (CSF), (ii) pre- $\mathrm{KMnO}_{4} / \mathrm{O}_{3} / \mathrm{K}_{2} \mathrm{FeO}_{4} / \mathrm{ClO}_{2}$ matched with CSF, and (iii) pre- $\mathrm{KMnO}_{4} / \mathrm{O}_{3} / \mathrm{K}_{2} \mathrm{FeO}_{4} / \mathrm{ClO}_{2}$ merged with $\mathrm{CSF}$ and pursued by granular activated carbon $(\mathrm{GAC}) / \mathrm{O}_{3}-\mathrm{GAC}$ advanced treatment. Micro-ozone pre-treatment integrated with $\mathrm{CSF}$ and $\mathrm{O}_{3}$-GAC illustrated the best efficiency in reducing chloroform (CF) and dichloracetonitrile (DCAN) precursors. Pre-oxidation had an unfavorable influence on chloropicrin (TCNM) and chloral hydrate generation, but a favorable influence on DCAN. Pre-oxidation $\left(\mathrm{KMnO}_{4}, \mathrm{O}_{3}, \mathrm{~K}_{2} \mathrm{FeO}_{4}\right.$, and $\left.\mathrm{ClO}_{2}\right)$ had a favorable impact on reducing overall cytotoxicity, and $\mathrm{O}_{3}$ pre-oxidation merged with CSF pursued by $\mathrm{O}_{3}$-GAC performed the best. Nevertheless, for reducing overall genotoxicity, the $\mathrm{ClO}_{2}$ pretreatment illustrated the best findings, whether or not GAC or $\mathrm{O}_{3}$-GAC was implied. Such findings remain useful for regulating the design of the treatment processes in drinking water treatment plants.

Zhang et al. [65] assessed the possibility of combining high-basicity polyaluminum chloride ( $\mathrm{PACl}$ ) and high-viscosity chitosan coagulating low-temperature and low-turbidity water. Higher-basicity $\mathrm{PACl}$ with a larger fraction of $\mathrm{Al}_{\mathrm{c}}$ (colloidal $\mathrm{Al}$ species in $\mathrm{PACl}$ ) and smaller portion of $\mathrm{Al}_{\mathrm{a}}$ (monomeric $\mathrm{Al}$ species in $\mathrm{PACl}$ ) was useful in reducing turbidity and NOM, as well as controlling the remaining $\mathrm{Al}$ content. Moreover, combining $\mathrm{PACl}$ with high basicity (90.3\%) and chitosan with high viscosity (500 $\mathrm{mPa} \cdot \mathrm{s}$ ) achieved the efficient reduction of turbidity and $\mathrm{NOM}$, with reduction performances of about $87 \%, 63 \%$, and $82 \%$ for turbidity, DOM and $\mathrm{UV}_{254}$, respectively (Figure 1). Larger and more settleable flocs tended to produce via the synergistic effect of charge neutralization by $\mathrm{Al}_{\mathrm{b}}$ (polymeric $\mathrm{Al}$ species in $\mathrm{PACl}$ ) and interparticle bridging by both the $\mathrm{Al}_{c}$ species and chitosan, as a result conducting to excellent coagulation efficiency. Such an investigation could give a helpful solution for dealing with low-temperature and low-turbidity water.

Besides EOM, IOM is also well removed by coagulation. IOM is also liberated from algae and is a significant precursor to DBPs in drinking water treatment [66]. Liu et al. [67] studied the coagulation efficacy of two $\mathrm{Al}$ salts: aluminum chloride $\left(\mathrm{AlCl}_{3}\right)$ and $\mathrm{PACl}$ (carrying $81.2 \% \mathrm{Al}_{13}$ ) focusing on the influence of $\mathrm{Al}$ species distribution on reducing IOM. PACl illustrated better performance than $\mathrm{AlCl}_{3}$ in terms of eliminating turbidity and DOM, thanks to the higher charge neutralization impact and greater stability of pre-formed $\mathrm{Al}_{13}$ species [68] [69]. The superiority of $\mathrm{PACl}$ in eliminating $\mathrm{DOM}$ can be attributed to the higher binding affinity between $\mathrm{Al}_{13}$ polymer and the low and medium $\mathrm{MW}$ fractions of IOM [70]. There is a more important production of complexes between $\mathrm{AlCl}_{3}$ and IOM, which benefits the reduction of tryptophan-like proteins thereafter. Moreover, $\mathrm{PACl}$ illustrated more important superiority juxtaposed to $\mathrm{AlCl}_{3}$ in 


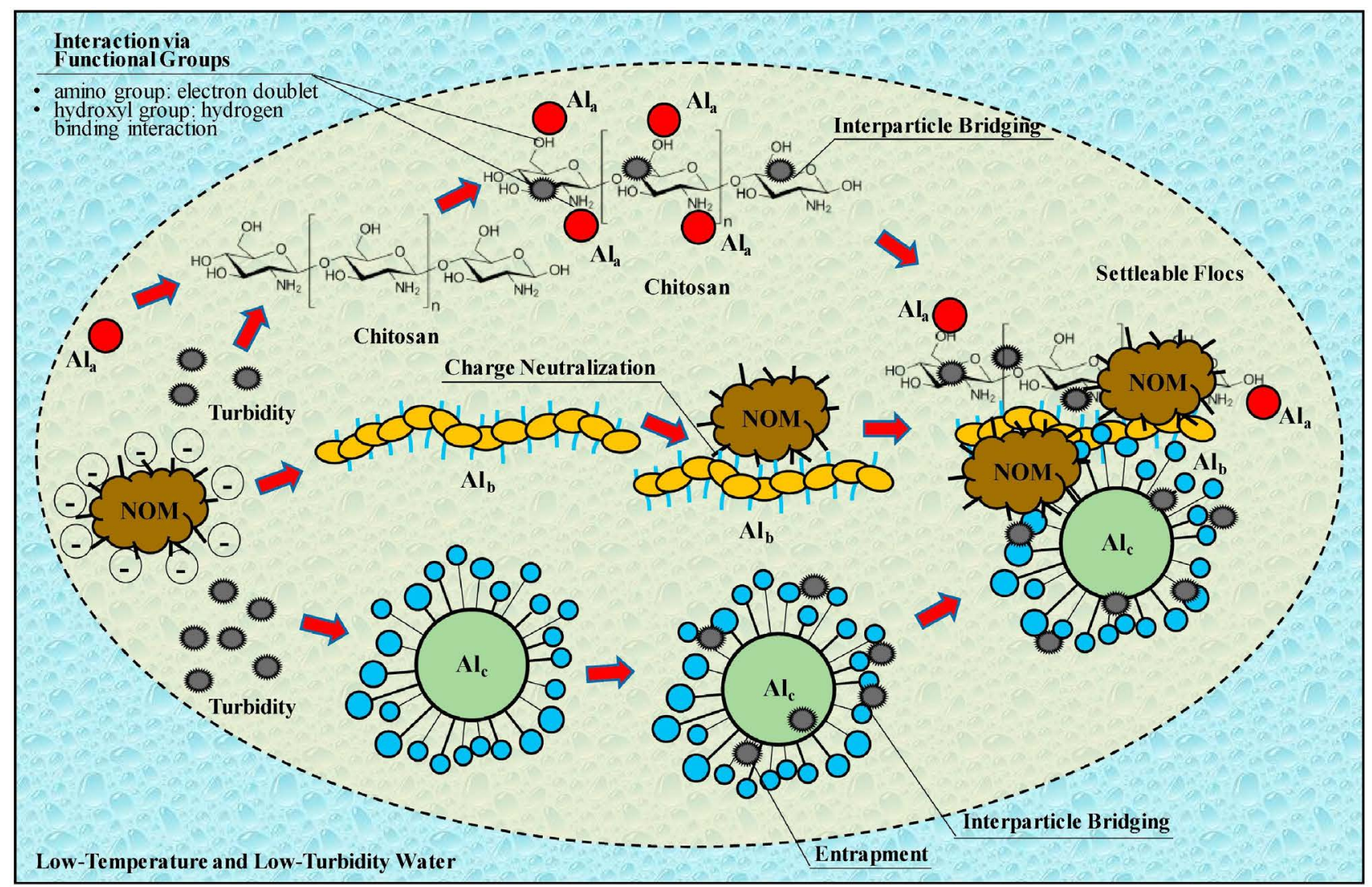

Figure 1. Schematic diagram for proposed mechanisms of applying high-basicity PAC combined with chitosan with high viscosity for removing turbidity, DOC, $\mathrm{UV}_{254}$ and simultaneously controlling residual Al content [65].

the reduction of $<5 \mathrm{kDa}$ and hydrophilic fractions, which are considered as the hardest to eliminate by coagulation.

In some countries like China, $M$. aeruginosa frequently blooms in summer whilst Cyclotella meneghiniana outbreaks in fall. As mentioned above, pre-oxidation can improve algae reduction before the coagulation stage. Nevertheless, the immoderate injection of pre-oxidant could augment the DBPs formation potential. Shi et al. [71] focused on the trichloromethane (TCM) formation, the changes of water quality indexes, and the morphology changes of algae from $M$. aeruginosa or $C$. meneghiniana contaminated water during $\mathrm{KMnO}_{4}$ or $\mathrm{Cl}_{2}$ pre-oxidation-coagulation-chlorination disinfection (Figure 2). TCM yield for the two algal species decreased with the injection augmentation of $\mathrm{KMnO}_{4}$ pre-oxidation, but increased with the injection augmentation of pre-chlorination. Consequently, the $2.0 \mathrm{mg} / \mathrm{L} \mathrm{KMnO}_{4}$ or $0.5 \mathrm{mg} / \mathrm{L} \mathrm{Cl}_{2}$ was suggested as the best injection for preventing both $M$. aeruginosa blooms in summer and for $C$. meneghiniana outbreaks in fall. $M$. aeruginosa showed a slightly higher TCM yield than $C$. meneghiniana in such techniques. Taking into account the liberation of $\mathrm{K}^{+}, \mathrm{KMnO}_{4}$ had less damage to cell integrity than $\mathrm{Cl}_{2}$ at the injection $\leq 2.0 \mathrm{mg} / \mathrm{L}$. Further, $C$. meneghiniana was easier to be disrupted by both pre-oxidants than $M$. aeruginosa, combining with subsequent coagulation led to different value of DOM, UV-visible absorbance $\left(\mathrm{UV}_{254}\right)$ and turbidity. 

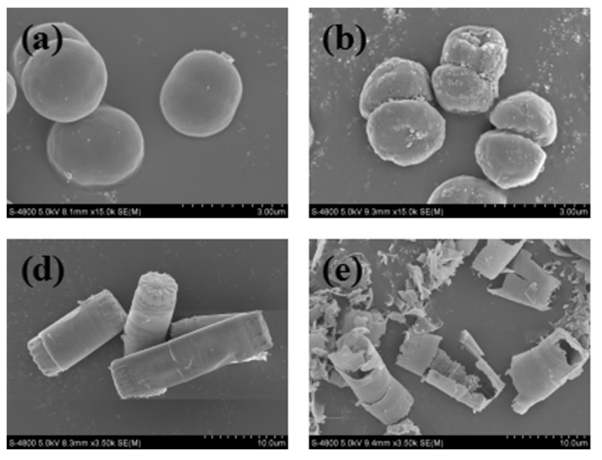
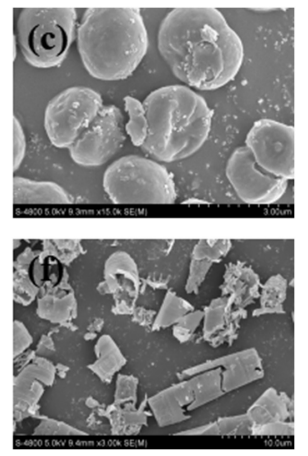

Figure 2. Scanning electron microscopy (SEM) of $M$. aeruginosa before pre-oxidation (a); after $2.0 \mathrm{mg} / \mathrm{L} \mathrm{KMnO}_{4}$ pre-oxidation (b); after $2.0 \mathrm{mg} / \mathrm{L}$ pre-chlorination (c); and SEM of $C$. meneghiniana before pre-oxidation (d); after $2.0 \mathrm{mg} / \mathrm{L} \mathrm{KnO}_{4}$ pre-oxidation (e); after $2.0 \mathrm{mg} / \mathrm{L}$ pre-chlorination (f). The experimental conditions are as follows: the concentration of $M$. aeruginosa and $C$. meneghiniana at $7.3 \times 10^{7}$ cells $/ \mathrm{L}$ and $2.1 \times 10^{7}$ cells/L, respectively, $\mathrm{pH}$ at $7.0 \pm 0.1$, and reaction time for $72 \mathrm{~h}$.

Hussain et al. [72] investigated the efficiency of titanium trichloride $\left(\mathrm{TiCl}_{3}\right)$ as a coagulant for surface water treatment and juxtaposed it with traditionally utilized aluminum sulfate (alum). $\mathrm{TiCl}_{3}$ illustrated a considerably bigger potential for reducing DOM at $\mathrm{pH} \sim 3$ at which charge neutralization was observed to be the governing pathway for the flocculation. Such a phenomenon was more obvious from the relatively bigger floc sizes obtained with $\mathrm{TiCl}_{3}$ application (Figure 3). Nevertheless, the destabilization of Ti-flocs took place at $\mathrm{pH} 4.5$ via an adsorption-enmeshment route because of highly negative zeta potential. Moreover, $\mathrm{TiCl}_{3}$ was more efficacious than alum in reducing humic substances. Combining alum and $\mathrm{TiCl}_{3}$, either as the same chemical or both, illustrated better effectiveness than a single injection implementation. $\mathrm{TiCl}_{3}$ can be an efficient solution for a water of low alkalinity and high DOM level and low $\mathrm{pH}$ wastewaters for the removal of hydrophobic compounds and particulate matter.

Several poisonous cyanobacteria manifest naturally with a filamentous, stacked cell arrangement named trichomes. Even if water treatment could be regulated to save cyanobacterial cells intact and avert the liberation of hazardous compounds, numerous physicochemical stresses encountered throughout the treatment technologies could lead to trichome truncation, reducing treatment efficacy by allowing single cells or short trichomes to reach the product water. This makes it easy for toxic compounds as well as OM to reach the distribution system. Pestana et al. [73] noted that genera (Pseudanabaena, Planktolyngbya) with short trichomes $(<10-12$ cells per trichome) are hardly influenced by the unit processes (loss of one to four cells respectively). However, genera (Planktothrix, Geitlerinema, Dolichospermum) with longer trichomes (30+ cells per trichome) suffer from high degrees of truncation (up to 63, 30, and 56 cells per trichome, respectively). The occurrence of a rigid sheath and/or mucilaginous layer seems to provide some protection from truncation. Some unit processes 

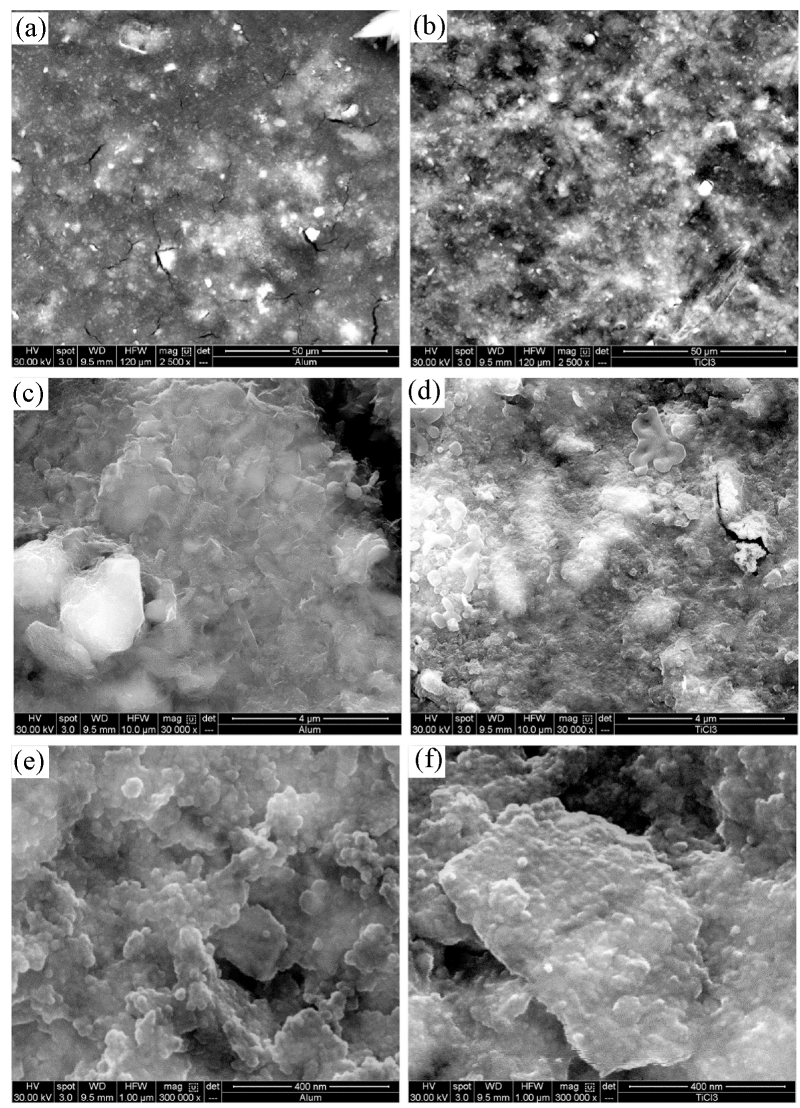

Figure 3. Micromorphology of alum (graphs (a), (c) and (e)) and $\mathrm{TiCl}_{3}$ (graphs (b), (d) and (f)) flocs formed at optimum $\mathrm{pH}$ (3 for $\mathrm{TiCl}_{3}$ and 6 for alum) and at coagulant dose of 16 $\mathrm{mg} / \mathrm{L}$, observed under SEM at various magnification levels (graphs a \& b, 2500×; c \& d, 30,00×; e \& f, 300,000×) [72].

change the sensitivity or resilience of trichomes to disruption by physical stress. Some genera (Planktothrix, Geitlerinema) were sensitive to pre-oxidation making them more susceptible to shear stress, whilst Dolichospermum sp. seems more robust after pre-oxidation. Whilst the possibility of toxicogenic genera breaking through into the product water remains a real danger, in their research, Pestana et al. [73] did not note toxicogenic cyanobacteria. There is a necessity for plant operators to study the incoming cyanobacterial composition in the raw water in order to adjust treatment parameters and thus limit the potential of hazardous compound breakthrough.

Thanks to its physicochemical impacts that are not identical to those of chemical applications, the ultrasonic technology is becoming more interesting [74] [75]. Indeed, high-frequency ultrasound is recognized as an efficient technique since the theoretical resonance frequency of the gas vesicles in $M$. aeruginosa is in the high-frequency range $(>100 \mathrm{kHz})$, which gives rise to gas vesicles collapse and alters the settleability of the algal cells. Li et al. [75] focused on the impacts of the ultrasonic frequency, acoustic power density, and duration on enhancing coagulation to reduce turbidity in algae-laden water. They examined 
the morphology of algae cells, the modifications in EOMs, the zeta potential, and the formation of hydroxyl radicals. The frequency showed fewer influences than power and duration on coagulation. More severe cellular damages took place at 430 and $740 \mathrm{kHz}$ than other frequencies. Sonication can induce the collapse of gas vesicles inside the cell (Figure 4). Such influence was attributed to the instantaneous high-pressure produced by the ultrasonic cavitation instead of the resonance. In addition, sonication would conduct to an elevation in proteins in EOM with continuous ultrasonic irradiation, showing that a small quantity of proteins can promote coagulation and that the accumulation of proteins would inhibit coagulation. Free radical content testing illustrated that the generation of excessive free radicals was frequently accompanied by a decrease in coagulation efficacy. The suitable mechanical impacts were the major pathway of ultrasonic EC. Consequently, the suitable ultrasonic condition was the one that conducted to a small amount of protein leakage and little formation of free radicals, which took place at $740 \mathrm{kHz}$ and $0.02 \mathrm{~W} / \mathrm{mL}$ in around $5 \mathrm{~min}$, and would significantly enhance the turbidity removal rate in algae-containing water from approximately $80 \%-90 \%$.

\section{Enhanced Coagulation (EC): Dares and Tendencies}

As seen above, EC stays a more technical tool to remove OM, algae, and turbidity. With the continuous contamination of surface water, harder targets have been adopted for EC [40] [76].
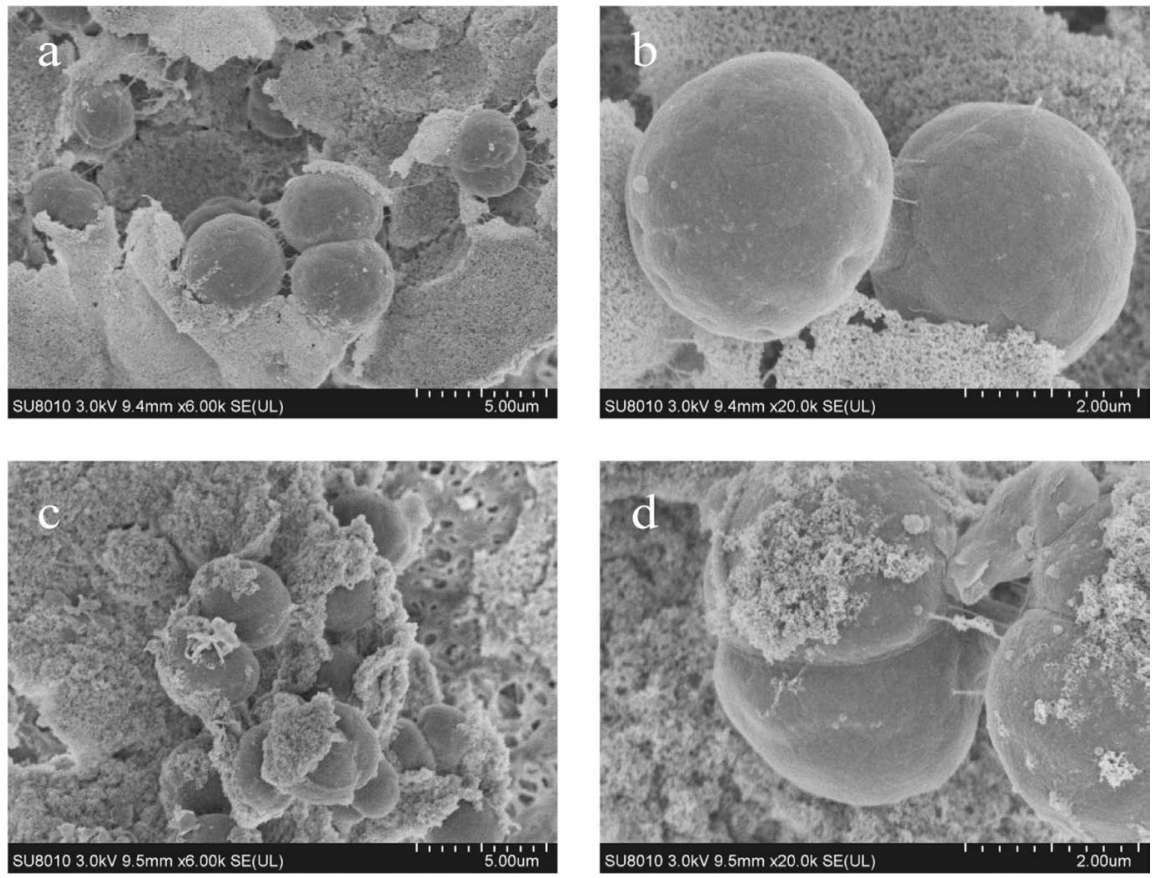

Figure 4. Flocs photos after coagulation: (a) flocs without sonication $(\times 6.00 \mathrm{k})$, (b) flocs without sonication $(\times 20.00 \mathrm{k})$, (c) flocs with sonication of $740 \mathrm{kHz}$ and $0.02 \mathrm{~W} / \mathrm{mL}$ for 5 $\min (\times 6.00 \mathrm{k}),(\mathrm{d})$ flocs with sonication of $740 \mathrm{kHz}$ and $0.02 \mathrm{~W} / \mathrm{mL}$ for $5 \mathrm{~min}(\times 20.00 \mathrm{k})$ [75]. 
Juxtaposed to the traditional coagulation, EC possesses considerable merits in increasing the elimination yield of DBPs and their precursors [77]. In addition, experimental optimization design employing orthogonal experimental design, response surface optimization design, uniform design and neural network system are employed [40] [76]. Such procedures could regulate the circumstances of EC dosage, $\mathrm{pH}$, etc., thus ameliorating the target of coagulation and decreasing the formation of coagulated sludge.

Saxena et al. [78] found that the $\mathrm{pH}$ at optimum doses was comprised between 6.5 and 8. Such finding proposed that reduction was mostly affected by sweep coagulation [7] and the full charge neutralization [7] was not probable (Figure 5). In the same context, eliminating DOM by coagulation correlated well with the hydrophobicity of the algal organic matter [79]. As a result, future researches have to focus on the sweep coagulation and charge neutralization mechanisms contributions [68] [76]. In this context, a sweep coagulation/charge neutralization ratio could be suggested similarly to the hydrophilic/hydrophobic ratio [39] proposed few years ago for better DOM removal monitoring. A coagulant-dose adjustment procedure founded on $\mathrm{UV}_{254}$ monitoring was applied at a full-scale plant [80]. For the large span of waters experimented, an alum/ $\mathrm{UV}_{254}$ stoichiometric injection of $180 \pm 25 \mathrm{mg}$ alum $\mathrm{cm} / \mathrm{L}$ shows a point of diminishing return (i.e., it maximizes DBP precursor removal).

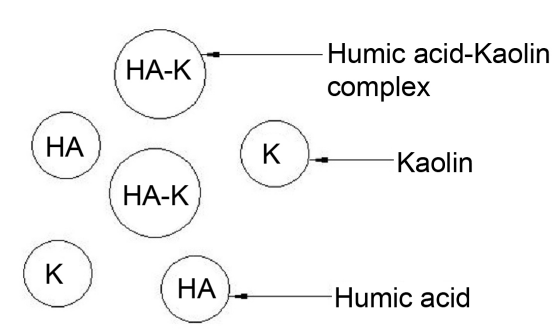

(a) Humic Acid-Kaolin simulated water

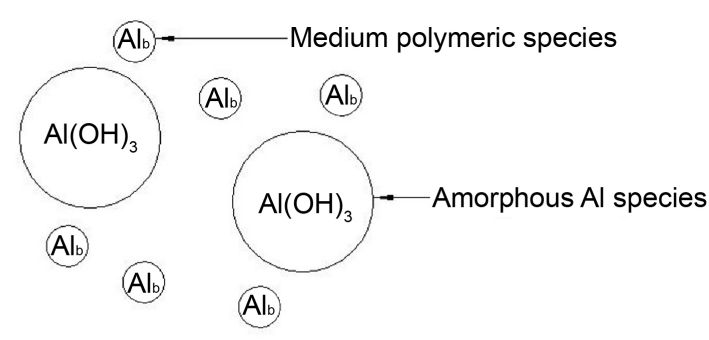

(b) Al species of High Basicity PACl at alkaline $\mathrm{pH}$

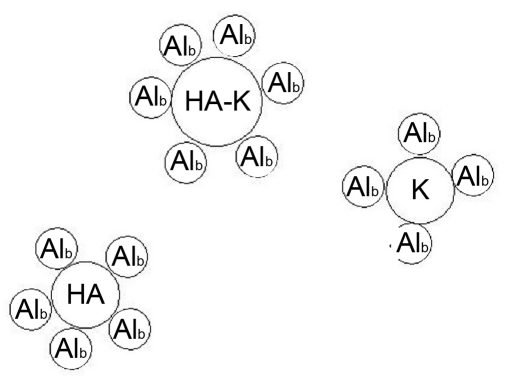

(c) Charge Neutralization

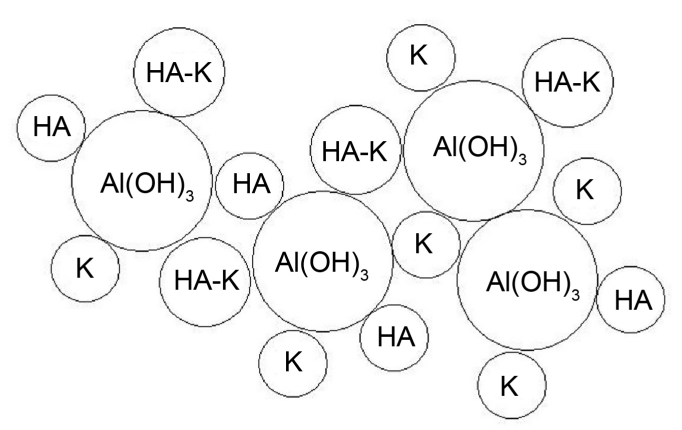

(d) Adsorption and entrapment

Figure 5. Schematic representation of possible mechanisms for mixed humic acid and kaolin removal [78]. 


\section{Conclusion}

Thanks to their easy functioning, high versatility, low energy consumption, and high-cost efficiency, coagulation and flocculation remain fundamental stages in the water treatment industry. This work discussed the usage of the EC method and focused on the performance of the EC technique from the point of view of various EC procedures. Pre-oxidation is largely utilized in dealing with water carrying algae. Pre-oxidation ameliorates coagulation by breaking the organic coating and modifying the surface potential of particles. Nevertheless, the pathway of pre-oxidative and coagulation stays totally unlike for numerous oxidants and pollutants. The present knowledge shows that EC remains founded on the pathway and dynamics of conventional coagulation. As long as the coagulation impact is considerably ameliorated, it could be adopted as EC. As a perspective, modeling mathematically EC is more than requested [81] [82]. Pre-oxidation techniques could be adopted to ameliorate raw water flocculation features, even if precautions should be adopted to avoid EOM release. Employing ozonation with GAC could also be adopted and estimated in situations where EC is utilized [13] [83] [84].

\section{Acknowledgements}

The Research Deanship of University of Ha'il, Saudi Arabia, through the Project RG-191190, has funded this research.

\section{Conflicts of Interest}

The author declares no conflicts of interest regarding the publication of this paper.

\section{References}

[1] Ghernaout, D. and Boucherit, A. (2015) Review of Coagulation's Rapid Mixing for NOM Removal. Journal of Research \& Developments in Chemistry, 2015, Article ID: 926518. https://doi.org/10.5171/2015.926518

[2] Ghernaout, B., Ghernaout, D. and Saiba, A. (2010) Algae and Cyanotoxins Removal by Coagulation/Flocculation: A Review. Desalination and Water Treatment, 20, 133-143. https://doi.org/10.5004/dwt.2010.1202

[3] Wongcharee, S., Aravinthan, V. and Erdei, L. (2020) Removal of Natural Organic Matter and Ammonia from Dam Water by Enhanced Coagulation Combined with Adsorption on Powdered Composite Nano-Adsorbent. Environmental Technology \& Innovation, 17, Article ID: 100557. https://doi.org/10.1016/j.eti.2019.100557

[4] Ghernaout, D. and Elboughdiri, N. (2020) Eliminating Cyanobacteria and Controlling Algal Organic Matter-Short Notes. Open Access Library Journal, 7, e6252. https://doi.org/10.4236/oalib.1106252

[5] Ghernaout, D. and Ghernaout, B. (2012) On the Concept of the Future Drinking Water Treatment Plant: Algae Harvesting from the Algal Biomass for Biodiesel Production-A Review. Desalination and Water Treatment, 49, 1-18. https://doi.org/10.1080/19443994.2012.708191

[6] Ghernaout, D., Elboughdiri, N., Ghareba, S. and Salih, A. (2020) Coagulation 
Process for Removing Algae and Algal Organic Matter-An Overview. Open Access Library Journal, 7, e6272. https://doi.org/10.4236/oalib.1106272

[7] Ghernaout, D. and Ghernaout, B. (2012) Sweep Flocculation as a Second Form of Charge Neutralisation-A Review. Desalination and Water Treatment, 44, 15-28. https://doi.org/10.1080/19443994.2012.691699

[8] Ghernaout, D., Ghernaout, B. and Naceur, M.W. (2011) Embodying the Chemical Water Treatment in the Green Chemistry-A Review. Desalination, 271, 1-10. https://doi.org/10.1016/j.desal.2011.01.032

[9] Ghernaout, D. (2013) The Best Available Technology of Water/Wastewater Treatment and Seawater Desalination: Simulation of the Open Sky Seawater Distillation. Green and Sustainable Chemistry, 3, 68-88. https://doi.org/10.4236/gsc.2013.32012

[10] Du, P., Li, X., Yang, Y., Su, Z., Li, H., Wang, N., Guo, T., Zhang, T. and Zhou, Z. (2019) Optimized Coagulation Pretreatment Alleviates Ultrafiltration Membrane Fouling: The Role of Floc Properties and Slow-Mixing Speed on Mechanisms of Chitosan-Assisted Coagulation. Journal of Environmental Sciences, 82, 82-92. https://doi.org/10.1016/j.jes.2019.02.027

[11] Ghernaout, D., Ghernaout, B. and Kellil, A. (2009) Natural Organic Matter Removal and Enhanced Coagulation as a Link between Coagulation and Electrocoagulation. Desalination, and Water Treatment, 2, 203-222. https://doi.org/10.5004/dwt.2009.116

[12] Ghernaout, D., Simoussa, A., Alghamdi, A., Ghernaout, B., Elboughdiri, N., Mahjoubi, A., Aichouni, M. and El-Wakil, A.E.A. (2018) Combining Lime Softening with Alum Coagulation for Hard Ghrib Dam Water Conventional Treatment. International Journal of Advances in Applied Sciences, 5, 61-70. https://doi.org/10.21833/ijaas.2018.05.008

[13] Cui, H., Huang, X., Yu, Z., Chen, P. and Cao, X. (2020) Application Progress of Enhanced Coagulation in Water Treatment. RSC Advances, 10, 20231-20244. https://doi.org/10.1039/D0RA02979C

[14] Wang, D.S., Zhao, Y.M., Yan, M.Q. and Chow, C.W.K. (2013) Removal of DBP Precursors in Micro-Polluted Source Waters: A Comparative Study on the Enhanced Coagulation Behavior. Separation and Purification Technology, 118, 271-278. https://doi.org/10.1016/j.seppur.2013.06.038

[15] Yan, M., Wang, D., Qu, J., Ni, J. and Chow, C.W.K. (2008) Enhanced Coagulation for High Alkalinity and Micro-Polluted Water: The Third Way through Coagulant Optimization. Water Research, 42, 2278-2286.

https://doi.org/10.1016/j.watres.2007.12.006

[16] Ghernaout, D., Badis, A., Braikia, G., Matâam, N., Fekhar, M., Ghernaout, B. and Boucherit, A. (2017) Enhanced Coagulation for Algae Removal in a Typical Algeria Water Treatment Plant. Environmental Engineering and Management Journal, 16, 2303-2315. https://doi.org/10.30638/eemj.2017.238

[17] Iriarte-Velasco, U., Álvarez-Uriarte, J.I. and González-Velasco, J.R. (2007) Enhanced Coagulation under Changing Alkalinity-Hardness Conditions and Its Implications on Trihalomethane Precursors Removal and Relationship with UV Absorbance. Separation and Purification Technology, 55, 368-380. https://doi.org/10.1016/j.seppur.2006.12.022

[18] Kellali, Y. and Ghernaout, D. (2019) Physicochemical and Algal Study of Three Dams (Algeria) and Removal of Microalgae by Enhanced Coagulation. Applied Engineering, 3, 56-64.

[19] Ghernaout, D., Al-Ghonamy, A.I., Boucherit, A., Ghernaout, B., Naceur, M.W., Ait 
Messaoudene, N., Aichouni, M., Mahjoubi, A. and Elboughdiri, N.A. (2015) Brownian Motion and Coagulation Process. American Journal of Environmental Protection, 4, 1-15. https://doi.org/10.11648/j.ajeps.s.2015040501.11

[20] Ghernaout, D. (2017) Entropy in the Brownian Motion (BM) and Coagulation Background. Colloid and Surface Science, 2, 143-161.

[21] Ghernaout, D. and Ghernaout, B. (2010) From Chemical Disinfection to Electrodisinfection: The Obligatory Itinerary? Desalination, and Water Treatment, 16, 156-175. https://doi.org/10.5004/dwt.2010.1085

[22] Djezzar, S., Ghernaout, D., Cherifi, H., Alghamdi, A., Ghernaout, B. and Aichouni, M. (2018) Conventional, Enhanced, and Alkaline Coagulation for Hard Ghrib Dam (Algeria) Water. World Journal of Applied Chemistry, 3, 41-55. https://doi.org/10.11648/j.wjac.20180302.12

[23] Boucherit, A., Moulay, S., Ghernaout, D., Al-Ghonamy, A.I., Ghernaout, B., Naceur, M.W., Ait Messaoudene, N., Aichouni, M., Mahjoubi, A. and Elboughdiri, N.A. (2015) New Trends in Disinfection By-Products Formation upon Water Treatment. Journal of Research \& Developments in Chemistry, 2015, Article ID: 628833. https://doi.org/10.5171/2015.628833

[24] Ghernaout, D. (2018) Disinfection and DBPs Removal in Drinking Water Treatment: A Perspective for a Green Technology. International Journal of Advances in Applied Sciences, 5, 108-117. https://doi.org/10.21833/ijaas.2018.02.018

[25] Ghernaout, D., Naceur, M.W. and Ghernaout, B. (2011) A Review of Electrocoagulation as a Promising Coagulation Process for Improved Organic and Inorganic Matters Removal by Electrophoresis and Electroflotation. Desalination, and Water Treatment, 28, 287-320. https://doi.org/10.5004/dwt.2011.1493

[26] Ghernaout, D. and Elboughdiri, N. (2019) Water Reuse: Emerging Contaminants Elimination-Progress and Trends. Open Access Library Journal, 6, e5981.

[27] Ghernaout, D. and Elboughdiri, N. (2020) Antibiotics Resistance in Water Mediums: Background, Facts, and Trends. Applied Engineering, 4, 1-6.

[28] Ghernaout, D. and Elboughdiri, N. (2020) Removing Antibiotic-Resistant Bacteria (ARB) Carrying Genes (ARGs): Challenges and Future Trends. Open Access Library Journal, 7, e6003. https://doi.org/10.4236/oalib.1106003

[29] Ghernaout, D. and Elboughdiri, N. (2020) Controlling Disinfection By-Products Formation in Rainwater: Technologies and Trends. Open Access Library Journal, 7, e6162. https://doi.org/10.4236/oalib.1106162

[30] Ghernaout, D. and Elboughdiri, N. (2020) Should We Forbid the Consumption of Antibiotics to Stop the Spread of Resistances in Nature? Open Access Library Journal, 7, e6138.

[31] Ghernaout, D. and Elboughdiri, N. (2020) Disinfection By-Products: Presence and Elimination in Drinking Water. Open Access Library Journal, 7, e6140.

[32] Ghernaout, D. and Elboughdiri, N. (2020) Foresight Look on the Disinfection By-Products Formation. Open Access Library Journal, 7, e6349.

[33] Ghernaout, D. and Elboughdiri, N. (2020) Disinfection By-Products Regulation: Zero ng/L Target. Open Access Library Journal, 7, e6382.

[34] Irki, S., Ghernaout, D. and Naceur, M.W. (2017) Decolourization of Methyl Orange (MO) by Electrocoagulation (EC) Using Iron Electrodes under a Magnetic Field (MF). Desalination, and Water Treatment, 79, 368-377. https://doi.org/10.5004/dwt.2017.20797

[35] Ghernaout, D. (2018) Magnetic Field Generation in the Water Treatment Perspec- 
tives: An Overview. International Journal of Advances in Applied Sciences, 5, 193-203. https://doi.org/10.21833/ijaas.2018.01.025

[36] Ghernaout, D. and Elboughdiri, N. (2020) Magnetic Field Application: An Underappreciated Outstanding Technology. Open Access Library Journal, 7, e6000.

[37] Park, K.-Y., Yu, Y.-J., Yun, S.-J. and Kweon, J.-H. (2019) Natural Organic Matter Removal from Algal-Rich Water and Disinfection Byproducts Formation Potential Reduction by Powdered Activated Carbon Adsorption. Journal of Environmental Management, 235, 310-318. https://doi.org/10.1016/j.jenvman.2019.01.080

[38] Ghernaout, D., Laribi, C., Alghamdi, A., Ghernaout, B., Ait Messaoudene, N. and Aichouni, M. (2018) Decolorization of BF Cibacete Blue (CB) and Red Solophenyle 3BL (RS) Using Aluminum Sulfate and Ferric Chloride. World Journal of Applied Chemistry, 3, 32-40. https://doi.org/10.11648/j.wjac.20180302.11

[39] Ghernaout, D. (2014) The Hydrophilic/Hydrophobic Ratio vs. Dissolved Organics Removal by Coagulation-A Review. Journal of King Saud University-Science, 26, 169-180. https://doi.org/10.1016/j.jksus.2013.09.005

[40] Sun, Y., Zhou, S., Chiang, P.-C. and Shah, K.J. (2019) Evaluation and Optimization of Enhanced Coagulation Process: Water and Energy Nexus. Water-Energy Nexus, 2, 25-36. https://doi.org/10.1016/j.wen.2020.01.001

[41] Ghernaout, D. and Elboughdiri, N. (2020) Dealing with Cyanobacteria and Cyanotoxins: Engineering Viewpoints. Open Access Library Journal, 7, e6363.

[42] Liu, Z., Wei, H., Li, A. and Yang, H. (2019) Enhanced Coagulation of Low-Turbidity Micro-Polluted Surface Water: Properties and Optimization. Journal of Environmental Management, 233, 739-747. https://doi.org/10.1016/j.jenvman.2018.08.101

[43] Jian, Z., Bai, Y., Chang, Y., Liang, J. and Qu, J. (2019) Removal of Micropollutants and Cyanobacteria from Drinking Water Using $\mathrm{KMnO}_{4}$ Pre-Oxidation Coupled with Bioaugmentation. Chemosphere, 215, 1-7.

https://doi.org/10.1016/j.chemosphere.2018.10.013

[44] Ghernaout, D. and Elboughdiri, N. (2019) Mechanistic Insight into Disinfection Using Ferrate(VI). Open Access Library Journal, 6, e5946.

[45] Ghernaout, D. and Elboughdiri, N. (2019) Water Disinfection: Ferrate(VI) as the Greenest Chemical-A Review. Applied Engineering, 3, 171-180.

[46] Ghernaout, D. and Naceur, M.W. (2011) Ferrate(VI): In Situ Generation and Water Treatment-A Review. Desalination, and Water Treatment, 30, 319-332. https://doi.org/10.5004/dwt.2011.2217

[47] Wert, E.C., Gonzales, S., Dong, M.M. and Rosario-Ortiz, F.L. (2011) Evaluation of Enhanced Coagulation Pretreatment to Improve Ozone Oxidation Efficiency in Wastewater. Water Research, 45, 5191-5199. https://doi.org/10.1016/j.watres.2011.07.021

[48] Ghernaout, D. and Elboughdiri, N. (2020) Towards Enhancing Ozone Diffusion for Water Disinfection-Short Notes. Open Access Library Journal, 7, e6253.

[49] Han, X., Lu, H., Gao, Y., Chen, X. and Yang, M. (2020) The Role of in Situ Fenton Coagulation on the Removal of Benzoic Acid. Chemosphere, 238, Article ID: 124632. https://doi.org/10.1016/j.chemosphere.2019.124632

[50] Ghernaout, D., Elboughdiri, N. and Ghareba, S. (2020) Fenton Technology for Wastewater Treatment: Dares and Trends. Open Access Library Journal, 7, e6045. https://doi.org/10.4236/oalib.1106045

[51] Pan, Y., Liu, Y., Wu, D., Shen, C., Ma, C., Li, F., Zhang, Y. and Ma, H. (2020) Application of Fenton Pre-Oxidation, Ca-Induced Coagulation, and Sludge Reclama- 
tion for Enhanced Treatment of Ultra-High Concentration Poly(vinylalcohol) Wastewater. Journal of Hazardous Materials, 389, Article ID: 121866. https://doi.org/10.1016/j.jhazmat.2019.121866

[52] Ghernaout, D., Moulay, S., Ait Messaoudene, N., Aichouni, M., Naceur, M.W. and Boucherit, A. (2014) Coagulation and Chlorination of NOM and Algae in Water Treatment: A Review. International Journal of Environmental Monitoring and Analysis, 2, 23-34. https://doi.org/10.11648/j.ijema.s.2014020601.14

[53] Ghernaout, D. (2017) Water Treatment Chlorination: An Updated Mechanistic Insight Review. Journal of Chemical Research, 2, 125-138.

[54] Ghernaout, D., Alghamdi, A., Aichouni, M. and Touahmia, M. (2018) The Lethal Water Tri-Therapy: Chlorine, Alum, and Polyelectrolyte. World Journal of Applied Chemistry, 3, 65-71. https://doi.org/10.11648/j.wjac.20180302.14

[55] Ghernaout, D., Al-Ghonamy, A.I., Naceur, M.W., Boucherit, A., Messaoudene, N.A., Aichouni, M., Mahjoubi, A. and Elboughdiri, N.A. (2015) Controlling Coagulation Process: From Zeta Potential to Streaming Potential. American Journal of Environmental Protection, 4, 16-27.

https://doi.org/10.11648/j.ajeps.s.2015040501.12

[56] Godo-Pla, L., Emiliano, P., Valero, F., Poch, M., Sinc, G. and Monclús, H. (2019) Predicting the Oxidant Demand in Full-Scale Drinking Water Treatment Using an Artificial Neural Network: Uncertainty and Sensitivity Analysis. Process Safety and Environmental Protection, 125, 317-327. https://doi.org/10.1016/j.psep.2019.03.017

[57] Ghernaout, D., Naceur, M.W. and Aouabed, A. (2011) On the Dependence of Chlorine By-Products Generated Species Formation of the Electrode Material and Applied Charge during Electrochemical Water Treatment. Desalination, 270, 9-22. https://doi.org/10.1016/j.desal.2011.01.010

[58] Ghernaout, D. and Elboughdiri, N. (2020) Is Not It Time to Stop Using Chlorine for Treating Water? Open Access Library Journal, 7, e6007.

[59] Ghernaout, D. (2019) Electrocoagulation Process for Microalgal Biotechnology-A Review. Applied Engineering, 3, 85-94.

[60] Ghernaout, D., Benblidia, C. and Khemici, F. (2015) Microalgae Removal from Ghrib Dam (Ain Defla, Algeria) Water by Electroflotation Using Stainless Steel Electrodes. Desalination, and Water Treatment, 54, 3328-3337. https://doi.org/10.1080/19443994.2014.907749

[61] Al Arni, S., Amous, J. and Ghernaout, D. (2019) On the Perspective of Applying of a New Method for Wastewater Treatment Technology: Modification of the Third Traditional Stage with Two Units, One by Cultivating Microalgae and Another by Solar Vaporization. International Journal of Environmental Sciences \& Natural Resources, 16, Article ID: 555934. https://doi.org/10.19080/IJESNR.2019.16.555934

[62] Ghernaout, D. and Elboughdiri, N. (2020) On the Other Side of Viruses in the Background of Water Disinfection. Open Access Library Journal, 7, e6374.

[63] Ghernaout, D., Irki, S. and Boucherit, A. (2014) Removal of $\mathrm{Cu}^{2+}$ and $\mathrm{Cd}^{2+}$, and Humic Acid and Phenol by Electrocoagulation Using Iron Electrodes. Desalination, and Water Treatment, 52, 3256-3270.

https://doi.org/10.1080/19443994.2013.852484

[64] Hu, J., Chu, W., Sui, M., Xu, B., Gao, N. and Ding, S. (2018) Comparison of Drinking Water Treatment Processes Combinations for the Minimization of Subsequent Disinfection By-Products Formation during Chlorination and Chloramination. Chemical Engineering Journal, 335, 352-361.

https://doi.org/10.1016/j.cej.2017.10.144 
[65] Zhang, Z., Jing, R., He, S., Qian, J., Zhang, K., Ma, G., Chang, X., Zhang, M. and Li, Y. (2018) Coagulation of Low Temperature and Low Turbidity Water: Adjusting Basicity of Polyaluminum Chloride (PAC) and Using Chitosan as Coagulant Aid. Separation and Purification Technology, 206, 131-139. https://doi.org/10.1016/j.seppur.2018.05.051

[66] Zhao, X. and Zhang, Y. (2011) Algae-Removing and Algicidal Efficiencies of Polydiallyldimethylammonium Chloride Composite Coagulants in Enhanced Coagulation Treatment of Algae-Containing Raw Water. Chemical Engineering Journal, 173, 164-170. https://doi.org/10.1016/j.cej.2011.07.058

[67] Liu, R., Guo, T., Ma, M., Yan, M., Qi, J., Hu, C., Liu, G., Liu, H., Qu, J. and van der Meer, W. (2019) Preferential Binding between Intracellular Organic Matters and $\mathrm{Al}_{13}$ Polymer to Enhance Coagulation Performance. Journal of Environmental Sciences, 76, 1-11. https://doi.org/10.1016/j.jes.2018.05.011

[68] Wang, P., Jiao, R., Liu, L., Xiao, F., An, G. and Wang, D. (2019) Optimized Coagulation Pathway of $\mathrm{Al}_{13}$ : Effect of In-Situ Aggregation of $\mathrm{Al}_{13}$. Chemosphere, 230, 76-83. https://doi.org/10.1016/j.chemosphere.2019.05.053

[69] Lin, J.-L. and Ika, A.R. (2020) Minimization of Halogenated DBP Precursors by Enhanced PACl Coagulation: The Impact of Organic Molecule Fraction Changes on DBP Precursors Destabilization with Al Hydrates. Science of the Total Environment, 703, Article ID: 134936. https://doi.org/10.1016/j.scitotenv.2019.134936

[70] Xiao, F., Xiao, P. and Wang, D. (2019) Influence of Allochthonous Organic Matters on Algae Removal: Organic Removal and Floc Characteristics. Colloid Surface A, 583, Article ID: 123995. https://doi.org/10.1016/j.colsurfa.2019.123995

[71] Shi, X., Bi, R., Yuan, B., Liao, X., Zhou, Z., Li, F. and Sun, W. (2019) A Comparison of Trichloromethane Formation from Two Algae Species during Two Pre-Oxidation Coagulation-Chlorination Processes. Science of the Total Environment, 656, 1063-1070. https://doi.org/10.1016/j.scitotenv.2018.11.461

[72] Hussain, S., Awad, J., Sarkar, B., Chow, C.W.K., Duan, J. and van Leeuwen, J. (2019) Coagulation of Dissolved Organic Matter in Surface Water by Novel Titanium (III) Chloride: Mechanistic Surface Chemical and Spectroscopic Characterization. Separation and Purification Technology, 213, 213-223. https://doi.org/10.1016/j.seppur.2018.12.038

[73] Pestana, C.J., Capelo-Neto, J., Lawton, L., Oliveira, S., Carloto, I. and Linhares, H.P. (2019) The Effect of Water Treatment Unit Processes on Cyanobacterial Trichome Integrity. Science of the Total Environment, 659, 1403-1414. https://doi.org/10.1016/j.scitotenv.2018.12.337

[74] Zhang, G., Zhang, P. and Fan, M. (2009) Ultrasound-Enhanced Coagulation for Microcystis aeruginosa Removal. Ultrasonics Sonochemistry, 16, 334-338. https://doi.org/10.1016/j.ultsonch.2008.10.014

[75] Li, Y., Shi, X., Zhang, Z. and Peng, Y. (2019) Enhanced Coagulation by High-Frequency Ultrasound in Microcystis aeruginosa-Laden Water: Strategies and Mechanisms. Ultrasonics Sonochemistry, 55, 232-242. https://doi.org/10.1016/j.ultsonch.2019.01.022

[76] Chaukura, N., Marais, S.S., Moyo, W., Mbali, N., Thakalekoala, L.C., Ingwani, T., Mamba, B.B, Jarvis, P. and Nkambule, T.T.I. (2020) Contemporary Issues on the Occurrence and Removal of Disinfection Byproducts in Drinking Water-A Review. Journal of Environmental Chemical Engineering, 8, Article ID: 103659. https://doi.org/10.1016/j.jece.2020.103659

[77] Yan, M., Wang, D., You, S., Qu, J. and Tang, H. (2006) Enhanced Coagulation in a 
Typical North-China Water Treatment Plant. Water Research, 40, 3621-3627. https://doi.org/10.1016/j.watres.2006.05.044

[78] Saxena, K., Brighu, U. and Choudhary, A. (2019) Coagulation of Humic Acid and Kaolin at Alkaline $\mathrm{pH}$ : Complex Mechanisms and Effect of Fluctuating Organics and Turbidity. Journal of Water Process Engineering, 31, Article ID: 100875. https://doi.org/10.1016/j.jwpe.2019.100875

[79] Zhao, Z., Sun, W., Ray, A.K., Mao, T. and Ray, M.B. (2020) Coagulation and Disinfection By-Products Formation Potential of Extracellular and Intracellular Matter of Algae and Cyanobacteria. Chemosphere, 245, Article ID: 125669. https://doi.org/10.1016/j.chemosphere.2019.125669

[80] Beauchamp, N., Bouchard, C., Dorea, C. and Rodriguez, M. (2020) Ultraviolet Absorbance Monitoring for Removal of DBP-Precursor in Waters with Variable Quality: Enhanced Coagulation Revisited. Science of the Total Environment, 717, Article ID: 137225. https://doi.org/10.1016/j.scitotenv.2020.137225

[81] Awad, J., Fisk, C.A., Cox, J.W., Anderson, S.J. and van Leeuwen, J. (2018) Modelling of THM Formation Potential and DOM Removal Based on Drinking Water Catchment Characteristics. Science of the Total Environment, 635, 761-768. https://doi.org/10.1016/j.scitotenv.2018.04.149

[82] Xie, J., Wang, D., van Leeuwen, J., Zhao, Y., Xing, L. and Chow, C.W.K. (2012) pH Modeling for Maximum Dissolved Organic Matter Removal by Enhanced Coagulation. Journal of Environmental Sciences, 24, 276-283. https://doi.org/10.1016/S1001-0742(11)60717-1

[83] Liu, H., Liu, R., Tian, C., Jiang, H., Liu, X., Zhang, R. and Qu, J. (2012) Removal of Natural Organic Matter for Controlling Disinfection By-Products Formation by Enhanced Coagulation: A Case Study. Separation and Purification Technology, 84, 41-45. https://doi.org/10.1016/j.seppur.2011.07.009

[84] Kristiana, I., Joll, C. and Heitz, A. (2011) Powdered Activated Carbon Coupled with Enhanced Coagulation for Natural Organic Matter Removal and Disinfection By-Product Control: Application in a Western Australian Water Treatment Plant. Chemosphere, 83, 661-667. https://doi.org/10.1016/j.chemosphere.2011.02.017 